\title{
Perancangan Sistem Informasi Surat Referendum Usulan Kenaikan Pangkat atau Jabatan Berbasis Web
}

\author{
Yudi Prabowo, Ike Pertiwi Windasari, Kodrat Imam Satoto \\ Program Studi Sistem Komputer Fakultas Teknik Universitas Diponegoro \\ Jalan Prof. Sudharto, Tembalang, Semarang, Indonesia \\ jackal.vs.ares@gmail.com
}

\begin{abstract}
The rapid growth of information and communication technology (ICT) facilitate human activity. Senate of the Faculty of Engineering, University of Diponegoro, as the highest representative body of normative and within the faculty , has one of the tasks that provide feedback on a proposed referendum letter promotion. In the current procedure, the data is stored in the form of the proposed paper form . This method is less efficient, time-consuming addition, members often did not give his opinion because of forgotten or busy with other activities. The purpose of this study is to design a new, computerized information system that is capable of handling data storage process in the Senate, a notice of the proposed promotion, and management approval of the proposed increase in the post.

Development of Information System was developed using FAST ( Framework for the Application of System Technique) . This information system development using PHP programming language ased on CodeIgniter framework. Storage and management of databases using a DBMS Database Management System MySQL . Testing Information System using User Acceptance testing, that using BlackBox Methodology .

The results of this study is to produce a system that can accommodate the proposed promotion, responses senate and spread in the form of an SMS message to the senate. So that this system can replace the system that is currently running are still less efficient and is manual .
\end{abstract}

Key Terms: information system, PHP, Senate promotion, FAST Metodology

\section{PEndahuluan}

$\mathrm{P}$ erkembangan teknologi informasi dan komunikasi yang pesat belakangan ini mampu menawarkan peningkatan efisiensi dan penghematan waktu dalam pekerjaan. Kemampuan itu dapat dimanfaatkan Senat Fakultas Teknik Universitas Diponegoro dalam memenuhi sebuah sistem informasi yang terkomputerisasi yang mampu menangani proses penyimpanan data anggota senat, pemberitahuan adanya usulan kenaikan jabatan, serta pengelolaan persetujuan atas usulan kenaikan jabatan tersebut.

\section{TINJAUAN PUSTAKA}

\section{A. Senat Fakultas}

Senat Fakultas adalah badan normatif dan perwakilan tertinggi di lingkungan fakultas yang memiliki wewenang untuk menjabarkan kebijakan dan Peraturan Universitas Diponegoro untuk fakultas yang bersangkutan[1]. Anggota Senat Fakultas terdiri atas Guru besar, Pimpinan Fakultas, Ketua Bagian dan perwakilan dosen di setiap bagian secara proporsional melalui proses pemilihan.

Senat Fakultas dipimpin oleh Ketua dan dibantu oleh seorang Sekretaris Senat yang dipilih dari dan oleh anggota Senat.

Senat Fakultas terdiri atas komisi-komisi, setiap komisi dipimpin oleh seorang ketua dibantu seorang sekretaris yang dipilih dari para anggota komisi.

Senat Fakultas mempunyai tugas pokok[2]:

1. Merumuskan baku mutu pendidikan, kebijakan akademik dan pengembangan fakultas;

2. Merumuskan kebijakan penilaian prestasi akademik. kecakapan dan kepribadian sivitas akademika;

3. Merumuskan norma, etika dan tolak ukur penyelenggaraan fakultas;

4. Menilai pertanggungjawaban dan pelaksanaan kebijakan yang telah ditetapkan oleh Pimpinan Fakultas;

5. Memberikan pertimbangan atas dosen yang dicalonkan memangku jabatan fungsional akademik lebih tinggi.

\section{B. Sistem Informasi}

Pengertian sistem informasi dari beberapa orang dalam buku Pengenalan Sistem Informasi, [3] :

a. Sistem informasi adalah kombinasi antara prosedur kerja,informasi,orang dan teknologi informasi yang diorganisasikan untuk mencapai tujuan dalam sebuah organisasi. [7]

b. Sistem informasi adalah sebuah rangkaian prosedur formal dimana data dikelompokan,diproses menjadi informasi dan didistribusikan kepada pemakai.[5]

c. Sebuah sistem informasi mengumpulkan, memproses, menyimpan, menganalisis dan menyebarkan informasi untuk tujuan yang spesifik.[6]

Dari berbagai definisi tersebut dapat disimpulkan bahwa sistem informasi mencakup sejumlah komponen (manusia,komputer,teknologi informasi dan prosedur kerja), ada sesuatu yang diproses (data menjadi informasi), dan dimaksudkan untuk mencapai suatu sasaran atau tujuan.

\section{PHP}

PHP bersifat open source sehingga dapat dipakai secara cuma-cuma dan mampu lintas platform, yaitu dapat berjalan pada sistem operasi Windows maupun Linux. PHP juga 
dibangun sebagai modul pada web server apache dan sebagai binary yang dapat berjalan sebagai CGI.[8]

Konsep pemrograman dengan PHP ini sedikit berbeda dengan pemrograman dengan menggunakan script CGI yang memaksa kita untuk selalu menulis kode yang menghasilkan keluaran dalam format HTML. Pada PHP, kita diberikan kebebasan untuk menyisipkan kode PHP di mana pun pada halaman HTML biasa dan menjalankan kode PHP tersebut setiap ada permintaan terhadap halaman tersebut.

Interpreter PHP dalam mengeksekusi kode PHP pada sisi server (disebut server-side) dan berbeda dengan mesin maya Java yang mengeksekusi program pada sisi client (clientside). Proses eksekusi kode PHP yang disisipkan pada halaman HTML secara diagram dapat digambar sebagai berikut.

\section{Codeigniter}

CodeIgniter adalah sebuah Framework Aplikasi, yaitu sebuah toolkit untuk membangun aplikasi web menggunakan PHP. Tujuannya adalah untuk memungkinkan programmer mengembangkan proyek-proyek lebih cepat daripada jika menulis kode dari awal, dengan menyediakan sekumpulan libraries untuk tugas yang biasa diperlukan, serta antarmuka yang sederhana dan struktur logis untuk mengakses libraries tersebut. CodeIgniter memungkinkan pengembang aplikasi fokus pada proyek dengan meminimalkan jumlah kode yang dibutuhkan untuk tugas yang diberikan.

CodeIgniter didasarkan pada pola pengembangan ModelView-Controller. MVC adalah sebuah pendekatan perangkat lunak yang memisahkan aplikasi logika dari presentasi. Dalam prakteknya, hal itu memungkinkan halaman web untuk memuat script kecil karena presentasi terpisah dari scripting PHP.

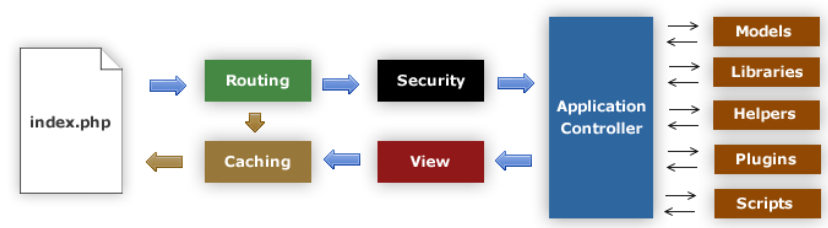

Gambar 1 Konsep Kerja Codeigniter

\section{E. $M y S Q L$}

MySQL adalah sebuah perangkat lunak sistem manajemen basis data SQL (bahasa Inggris: database management system) atau DBMS yang multithread, multi-user, dengan sekitar 6 juta instalasi di seluruh dunia. MySQL AB membuat MySQL tersedia sebagai perangkat lunak gratis di bawah lisensi GNU General Public License (GPL), tetapi mereka juga menjual di bawah lisensi komersial untuk kasus-kasus di mana penggunaannya tidak cocok dengan penggunaan GPL.

\section{PERANCANGAN PENELITIAN}

Pengembangan perangkat lunak yang dilakukan mengikuti metodologi FAST (Framework for Application Sistem Technologies) dan melaksanakan tahapan pengembangan mulai dari tahap scope definition, problem analysis, requirement analysis, logical design, decission analysis, physical design and integration, construction and testing, tanpa melakukan tahapan installation and delivery pada sistem nyata [7].

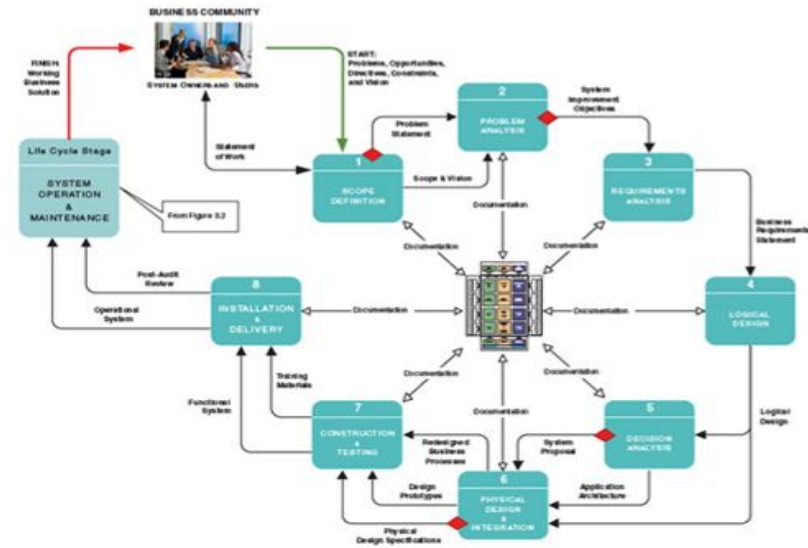

Gambar 2 Metode FAST

A. Scope Definition

Tujuan utama penelitian adalah untuk mengembangkan perangkat lunak sebagai bagian dari Sistem Informasi Senat Fakultas Teknik Universitas Diponegoro Semarang.

Pemilik proyek adalah senat fakultas teknik. Pihak-pihak yang terlibat dalam pengembangan perangkat lunak adalah pemilik proyek dalam hal ini diwakili oleh perwakilan anggota senat, sistem analyst, dan programmer program aplikasi.

Anggaran biaya dan jadwal tidak menjadi kajian dalam pengembangan perangkat lunak.

\section{B. Analisis Masalah}

Analisis yang pertama kali dilakukan adalah analisis terhadap sistem yang berjalan. Analisis sistem berjalan berfungsi untuk menguraikan sebuah sistem menjadi bagianbagian dengan tujuan mempelajari seberapa baik komponen tersebut berinteraksi untuk meraih tujuan. Diagram alir kerja sistem yang berjalan saat ini ditunjukkan pada gambar 3.2.

Memenuhi fungsi senat untuk memberikan pendapat tentang usulan kenaikan jabatan fungsional akademik, anggota senat Fakutas Teknik Undip memiliki tatacara tersendiri. Salah satunya, usulan atas kenaikan pangkat dan jabatan fungsional di informasikan melalui surat edaran referendum kepada anggota senat.

Surat edaran memuat informasi nomor surat, tanggal surat, perihal dan isi usulan. Isi usulan terdiri atas nama pegawai, NIP, jurusan, pangkat dan jabatan lama, TMT, pangkat, dan jabatan yang diusulkan. Di bagian akhir surat diberikan form isian atas tanggapan anggota senat terhadap usulan yang diberikan. Tanggapan bisa dalam pernyataan setuju atau tidak setuju. Setuju atau tidak setuju dalam hal kenaikan pangkat, kenaikan jabatan, atau kenaikan pangkat dan jabatan. Apabila dalam 10 hari surat edaran tidak disampaikan kembali kepada Sekretaris Senat, maka anggota dianggap setuju atas usulan.

Dalam praktiknya, sering terjadi kendala sebagai berikut :

1. Distribusi surat edaran lambat. Surat edaran referendum tidak diterima oleh anggota senat sesuai tanggal surat.

2. Anggota senat tidak menerima atau belum mengetahui akan adanya surat edaran referendum dikarenakan urusan dinas atau urusan pribadi.

3. Sebagian anggota senat tidak memberikan/mengembalikan surat tanggapan kepada sekretaris senat.

4. Sekretaris senat menerima surat tanggapan melebihi waktu yang diberikan.

5. Dibutuhkan waktu bagi sekretaris senat untuk melakukan rekapitulasi dan menyusun laporan hasil referendum.

6. Pelaksanaan prosedur referendum dari awal sampai akhir memakan waktu lebih dari 10 hari. 
7. Sekretaris senat membutuhkan media untuk mengumumkan hasil referendum kepada anggota senat
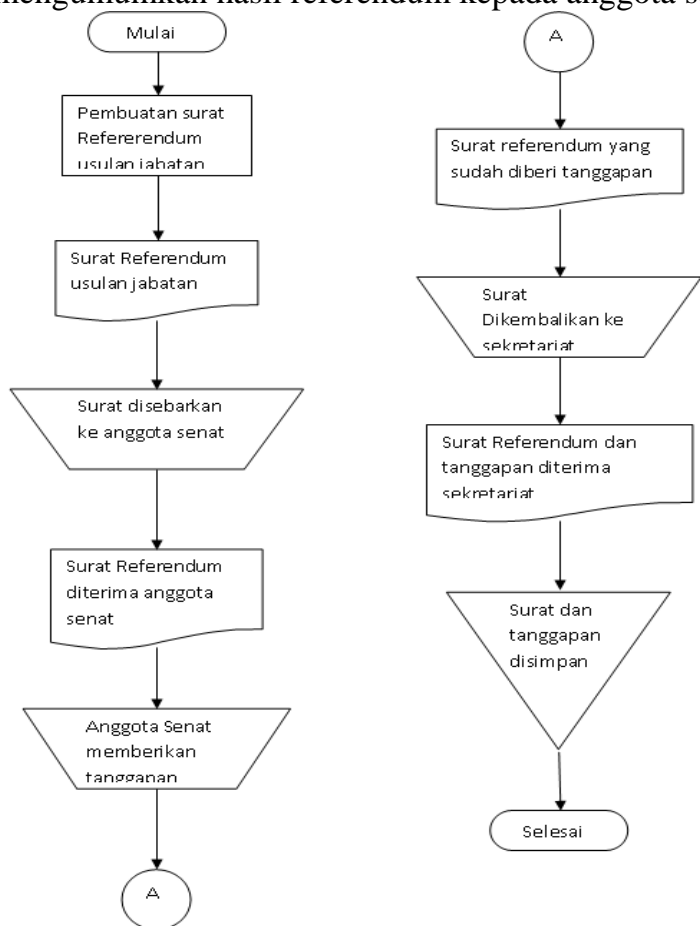

Gambar 3 Flowchart penyebaran surat referendum

\section{Analisis Kebutuhan}

Dengan mempelajari sistem yang berjalan, didapatkan beberapa kebutuhan sistem yaitu:

a. Kebutuhan Fungsional

Aktifitas dan layanan yang harus diberikan atau disediakan :

1) Sistem harus menyediakan sarana untuk mengelola data usulan pangkat dan jabatan (data referendum) bagi administrator atau sekretaris senat. Informasi referendum juga harus dapat diberikan lampiran berkas-berkas pendukung.

2) Sistem menyediakan tools untuk broadcast pesan pemberitahuan adanya referendum baru kepada seluruh anggota senat. Teknik broadcast dapat berupa mengirimkan pesan melalui SMS (Short Message Service).

3) Sistem harus menyediakan sarana bagi anggota senat untuk memberikan tanggapan. Tanggapan harus dapat di ubah lagi selama masa aktif referendum belum berakhir.

4) Hasil referendum harus ditampilkan segera oleh sistem. Tampilan referendum dapat berupa grafik maupun tabel. Informasi yang diberikan berbentuk ringkas, tetapi harus mampu dicari detail informasinya.

5) Sistem menyediakan fungsi login sebagai pintu masuk ke sistem untuk autentifikasi penggunaan dan membedakan hak akses/wewenang pengguna.

6) Sistem harus dapat menyediakan fasilitas kelola pengguna dan kelola group pengguna bagi administrator sistem.

7) Sistem harus menyediakan fasilitas menampilkan berita

b. Kebutuhan Non Fungsional

Kebutuhan Non Fungsional yaitu fitur, karakteristik, dan batasan lainnya yang menentukan apakah sistem memuaskan atau tidak. Berikut ini kebutuhan non-fungsional Sistem Informasi Senat Fakultas Teknik Undip :

1) Sistem harus memberikan respon yang cepat dalam hal pemasukan data, pencarian data, dan menampilkan laporan.

2) Sistem harus dapat diakses dengan baik di komputer.

\section{Logical Design}

Berdasarkan kebutuhan yang dijabarkan sebelumnya, maka didapatkan perancangan logika fungsionalitas yang akan dimiliki oleh sistem yang direpresentasikan melalui usecase diagram berikut ini:

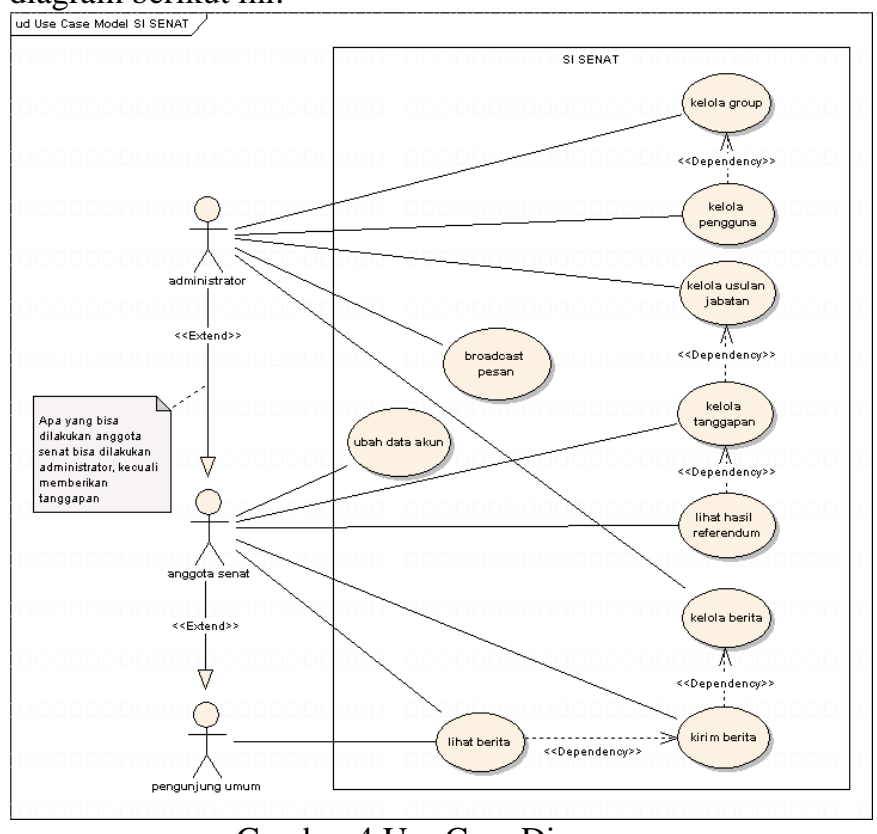

Gambar 4 Use Case Diagram

\section{E. Analisis Keputusan}

Analisis keputusan dapat dilakukan menggunakan beberapa pertimbangan :

1. Technical visibity

Secara teknologi masih memungkinkan perangkat lunak dibuat.

2. Operational visibility

Perangkat lunak berbasis website dan penggunaan perangkat telepon seluler, notebook, ataupun personal computer dapat dioperasikan oleh seluruh pengguna sistem.

3. Economic visibility

Biaya kemungkinan akan dikeluarkan lebih besar diawal pengembangan sistem untuk pembuatan perangkat lunak dan sosialisasi/training ke pengguna. Tetapi setelah itu, biaya operasional yang dikeluarkan oleh senat jauh lebih sedikit/lebih kecil dibandingkan dengan biaya operasional sistem lama. Biaya yang ditanggung setelah sistem berjalan hanya pada biaya pembelian domain dan hosting program aplikasi (website).

4. Schedule visibility

Jadwal tidak menjadi kendala dalam pengembangan aplikasi. Artinya perangkat lunak tidak harus dibuat tergesa-gesa karena akan segera digunakan.

\section{F. Physical design and integration}

Pengembangan perangkat lunak atau akan menggunakan bahasa script HTML, PHP, CSS, dan javascript. HTML untuk memberikan struktur bagi halaman web, PHP untuk logika program dan interaksi dengan basisdata, CSS untuk memperbaiki penampilan halaman web, dan javascript yang menangani validasi input dan interaktivitas halaman web.

Hubungan antara komponen-komponen tersebut didalam server digambarkan sebagai berikut : 


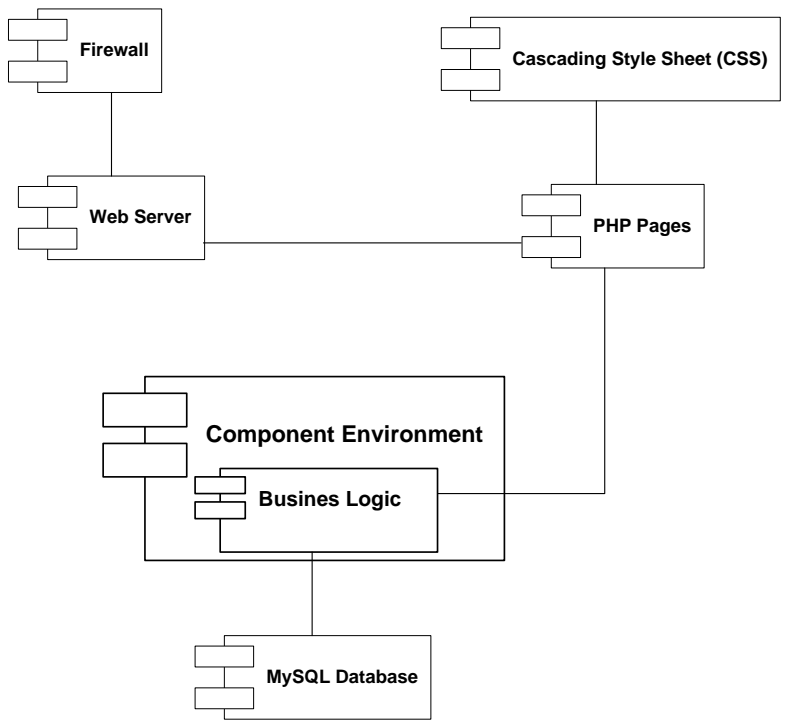

Gambar 5 Component Diagram Komputer Server

\section{IMPLEMENTASI DAN PENGUJIAN}

\section{A. Implementasi Aplikasi}

Hasil analisis dan perancangan sistem informasi senat fakultas teknik undip diimplementasikan menggunakan bahasa pemrograman berbasis web PHP mengikuti framework codeigniter. Pemilihan teknologi ini telah dijelaskan pada proses analisis.

Web server yang digunakan dalam pengembangan adalah Apache. Selain web server di computer server juga harus tepasang database management system (DBMS) sebagai aplikasi penyimpan dan pengelola data. DBMS yang digunakan adalah MySQL. Fungsi SMS Broadcast diimplementasi menggunakan bantuan gammu sms gateway.

Sistem informasi senat fakultas teknik undip memiliki kemampuan untuk :

1. Membantu sekretaris senat dalam menyebarkan surat edaran referendum kenaikan pangkat pegawai melalui jalur komunikasi berbasis web.

2. Menyebarkan informasi adanya surat edaran referendum baru kepada anggota senat melalui SMS (Short Message Service).

3. Menampung tanggapan dari setiap anggota senat mengenai sebuah surat edaran referendum kenaikan pangkat dan jabatan pegawai berbasis web.

4. Memberikan informasi / laporan hasil referendum kepada seluruh anggota senat.

Hasil pemrograman sistem informasi referendum senat fakultas teknik undip diperlihatkan dengan contoh printscreen tampilan program ketika dijalankan berikut ini:

1. Halaman Utama

Halaman utama adalah halaman yang pertama kali diberikan oleh sistem ketika pengguna mengakses halaman website. Halaman ini menampilkan beberapa artikel berita dan form login untuk anggota senat.

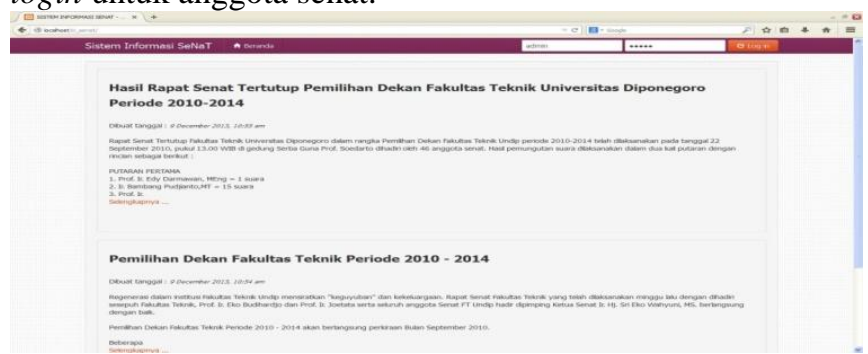

Gambar 6 Printscreen tampilan halaman utama
2. Halaman Kelola Usulan Jabatan

Data usulan jabatan dikelola oleh administrator sistem. Mengelola berarti administrator bisa menambah data usulan, mencari data usulan, melihat detail data usulan, mengedit data usulan, menghapus data usulan, atau melihat hasil referendum.

Berikut ini adalah tampilan yang diberikan saat administrator mengakses menu kelola usulan jabatan :

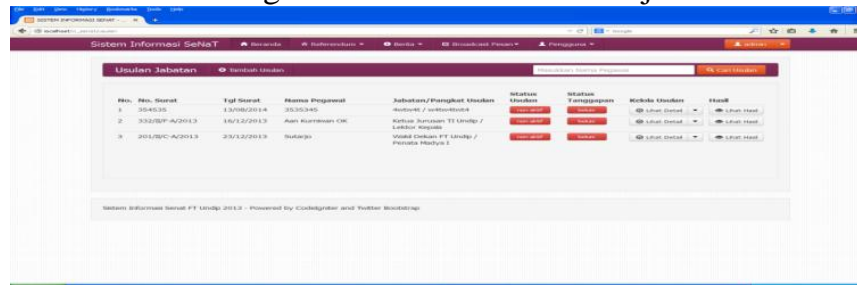

Gambar 7 Printscreen halaman kelola usulan jabatan

3. Halaman Memberikan Tanggapan

Fungsi memberikan tanggapan dapat dilakukan oleh setiap anggota senat. Pengguna/anggota senat harus login terlebih dahulu dan mengakses menu referendum usulan jabatan. Tampilan yang diberikan oleh menu referendum usulan jabatan adalah daftar usulan jabatan yang diinput oleh admin.

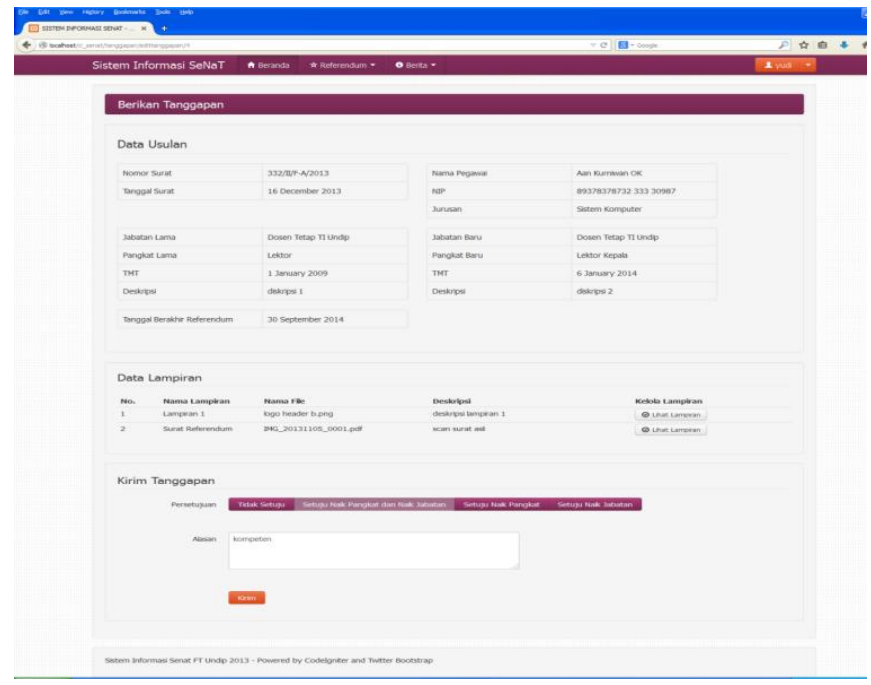

Gambar 8 Printscreen Halaman Memberikan Tanggapan

4. Halaman Lihat Hasil Referendum

Hasil referendum dapat dilihat dengan memilih/klik tombol lihat hasil pada sebuah usulan jabatan. Tampilan yang diberikan adalah data detil usulan jabatan, grafik tanggapan berbentuk pie chart dan bar chart, dan tabel seluruh tanggapan yang telah masuk. Apabila bar chart di klik, maka akan menampilkan detil/daftar pemberi tanggapan.

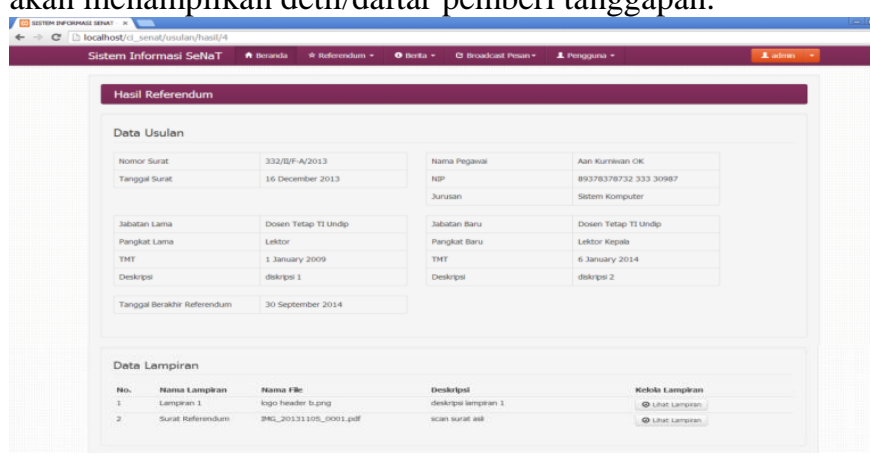




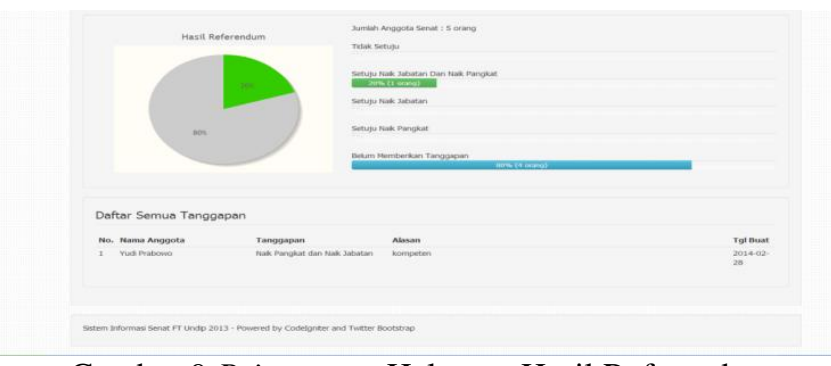

Gambar 9 Printscreen Halaman Hasil Referendum

\section{B. Metode Pengujian}

Selain untuk mencari kesalahan pemrograman, pengujian juga digunakan untuk melakukan verifikasi dan validasi hasil terhadap perancangan dan analisis. Secara lengkap pengujian mengikuti model V yang digambarkan oleh Pressman (2010) sebagai berikut :

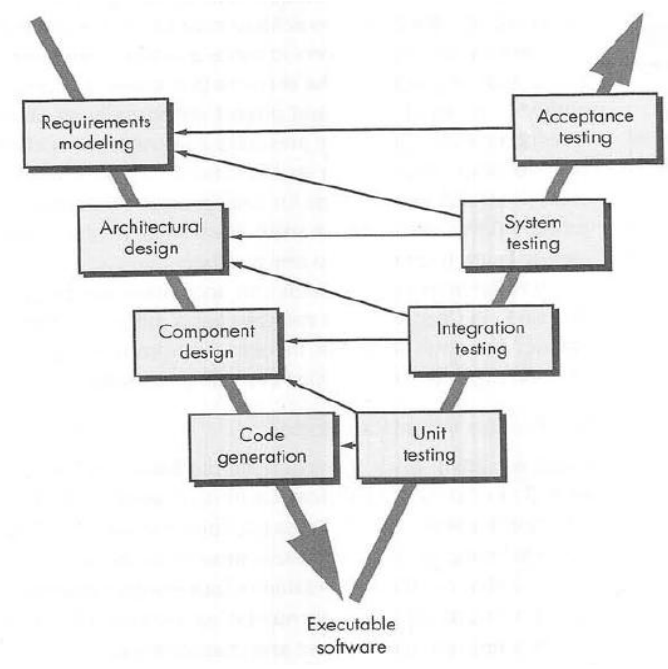

Gambar 10 Pengujian Metode model V

Pengujian pertama kali dilakukan sejak code program dibuat. Ketika sebuah kode atau sebuah file program selesai dibuat, programmer segera melakukan pengujian yang disebut dengan unit testing. Setelah file dihasilkan dan diorganisasikan maka dilakukan integration testing. Integration testing mencoba menguji apakah file-file dapat bekerjasama mewujudkan fungsi yang diharapkan.Berikutnya dilakukan system testingdengan merujuk pada rancangan teknis dan kebutuhan sistem/usecase.Terakhir dilakukan acceptance testing dimana developer bersama-sama dengan owner/pemilik project/real user untuk mendapat persetujuan bahwa programtelah berjalan dengan baik sesuai dengan usecase/requirementyang diharapkan.

\section{Hasil Pengujian}

Pengujian dilakukan dengan teknik pengujian Black Box yaitu :

a) Menguji fungsi-fungsi khusus dari perangkat lunak yang dirancang. Fungsi khusus merujuk pada usecase hasil analisis sistem.

b)Kebenaran perangkat lunak yang diuji hanya dilihat berdasarkan keluaran (output) yang dihasilkan dari data atau kondisi masukan yang diberikan untuk fungsi yang ada tanpa melihat bagaimana proses untuk mendapatkan keluaran tersebut. Dari keluaran yang dihasilkan, kemampuan program dalam memenuhi kebutuhan pemakai dapat diukur sekaligus dapat diketahui kesalahan-kesalahannya. c) Identifikasi dikelompokkan berdasarkan Software Requirement Specification (SRS) dan User Acceptence Testing (UAT).

Tabel 1 Daftar Hasil Pengujian

\begin{tabular}{|c|c|c|c|c|}
\hline Kelas Uji & Usecase & $\begin{array}{l}\text { Tingkat } \\
\text { Pengujian }\end{array}$ & $\begin{array}{l}\text { Jenis } \\
\text { Pengujia } \\
\text { n }\end{array}$ & Status \\
\hline $\begin{array}{l}\text { 1.Melihat } \\
\text { berita }\end{array}$ & SRS-1 & $\begin{array}{l}\text { Pengujian } \\
\text { Sistem }\end{array}$ & Black Box & Berhasil \\
\hline $\begin{array}{l}\text { 2.Login } \\
\text { (Autentifikasi) }\end{array}$ & SRS-2 & $\begin{array}{l}\text { Pengujian } \\
\text { Sistem }\end{array}$ & Black Box & Berhasil \\
\hline $\begin{array}{l}\text { 3.Mengolola } \\
\text { group }\end{array}$ & SRS-3 & $\begin{array}{l}\text { Pengujian } \\
\text { Sistem }\end{array}$ & Black Box & Berhasil \\
\hline $\begin{array}{l}\text { 4.Mengolola } \\
\text { pengguna }\end{array}$ & SRS-4 & $\begin{array}{l}\text { Pengujian } \\
\text { Sistem }\end{array}$ & Black Box & Berhasil \\
\hline 5. Ubah Akun & SRS-5 & $\begin{array}{l}\text { Pengujian } \\
\text { Sistem }\end{array}$ & Black Box & Berhasil \\
\hline $\begin{array}{l}\text { 6.Mengolola } \\
\text { usulan jabatan }\end{array}$ & SRS-6 & $\begin{array}{l}\text { Pengujian } \\
\text { Sistem }\end{array}$ & Black Box & Berhasil \\
\hline $\begin{array}{l}\text { 7.Broadcast } \\
\text { pesan }\end{array}$ & SRS-7 & $\begin{array}{l}\text { Pengujian } \\
\text { Sistem }\end{array}$ & Black Box & Berhasil \\
\hline $\begin{array}{l}\text { 8. Memberikan } \\
\text { tanggapan }\end{array}$ & SRS-8 & $\begin{array}{l}\text { Pengujian } \\
\text { Sistem }\end{array}$ & Black Box & Berhasil \\
\hline $\begin{array}{l}\text { 9.Melihat hasil } \\
\text { referendum }\end{array}$ & SRS-9 & $\begin{array}{l}\text { Pengujian } \\
\text { Sistem }\end{array}$ & Black Box & Berhasil \\
\hline $\begin{array}{l}\text { 10.Mengirim } \\
\text { berita }\end{array}$ & SRS-10 & $\begin{array}{l}\text { Pengujian } \\
\text { Sistem }\end{array}$ & Black Box & Berhasil \\
\hline $\begin{array}{l}\text { 11.Mengelola } \\
\text { berita }\end{array}$ & SRS-11 & $\begin{array}{l}\text { Pengujian } \\
\text { Sistem }\end{array}$ & Black Box & Berhasil \\
\hline
\end{tabular}

\section{KESIMPULAN DAN SARAN}

Pada bagian ini akan dijelaskan kesimpulan dan saran dari hasil penelitian dan pembahasan.

A. Kesimpulan

Berdasarkan hasil penelitian dan pembahasan, maka dapat diambil kesimpulan sebagai berikut :

1. Sistem informasi ini melakukan penyebaran Surat Referendum Usulan Kenaikan Jabatan di lingkungan fakultas teknik. Penyebaran ini dilakukan melalui media berbasis web sehingga setiap anggota senat dapat memberikan tanggapannya melalui web tersebut.

2. Sistem informasi ini merupakan suatu aplikasi yang digunakan untuk membantu penyebaran Surat Referendum Usulan Kenaikan Jabatan. Penggunaan aplikasi akan meningkatkan penyebaran surat menjadi lebih mudah dan efisien dilakukan, aman karena data tersimpan dalam database, tidak cepat rusak, mempermudah dalam pencarian data, serta lebih menjamin setiap surat dapat diterima anggota senat selama dapat terhubung ke web tersebut.

3. Fungsi aplikasi ini adalah sebagai berikut,

a. Menyimpan data akun anggota senat , sebagai otentifikasi pada saat login pada system informasi ini.

b. Menyebarkan Surat Referendum Usulan Kenaikan Jabatan kepada setiap akun anggota senat dengan menyertakan lampiran Surat Resmi melalui media web.

c. Menampung tanggapan setiap anggota senat melalui form yang disediakan untuk setiap Surat Referendum Usulan Kenaikan Jabatan. 
d. Menampilkan hasil dari tanggapan yang diberikan oleh anggota senat pada setiap Surat Referendum Usulan Kenaikan Jabatan.

4. Penggunaan Codeigniter sebagai framework pembangun sistem informasi ini mempermudah dalam organisasi kode dan proses maintenance, sedangkan CSS framework digunakan untuk memperindah tampilan dari sistem informasi.

B. Saran

Terdapat beberapa saran dari hasil penelitian yaitu sebagai berikut :

1. Sistem informasi ini dapat dikembangkan menjadi sistem yang lebih besar dan diintegrasikan dengan modulmodul yang lain.

2. Sistem informasi ini juga dapat dikembangkan lebih jauh lagi agar aplikasi ini layak disebut sistem informasi ditinjau dari segi fungsionalitas keluaran dan keamanannya sehingga dapat benar-benar menggantikan proses kerja manual yang dilakukan sebelumnya.

\section{DAFTAR PUSTAKA}

[1]. PERATURAN UNIVERSITAS DIPONEGORO NOMOR 1 TAHUN 2010 TENTANG TATA CARA PEMILIHAN PIMPINAN UNIVERSITAS DIPONEGORO DAN PIMPINAN FAKULTAS PADA UNIVERSITAS DIPONEGORO

[2]. PERATURAN PEMERINTAH REPUBLIK INDONESIA NOMOR 60 TAHUN 1999 TENTANG PENDIDIKAN TINGGI

[3]. Abdul Kadir.2002. Pengenalan Sistem Informasi. Andi.Yogyakarta

[4]. Hans-Erik Eriksson dan Manus Penker. UML Toolkit. 1998

[5]. Hall, James A. (2001). Sistem Informasi Akuntansi. Terjemahan Jusuf Salemba Empat,. Jakarta.

[6]. Turban, Enfraim., McCean, Ephraim., Waterbe, James. 1999. Information Technology for Management Making Connection for strategies advantages. 2th Edition, John Wiley \& Soon, Inc.

[7]. Alter, Steven. 1992. Information System : A Management Perspective. The Benjamin/cummings publishing company, Inc. (Memuat informasi mengenai definisi sistem informasi).

[8]. Azis. M. Farid. (2001). Belajar Sendiri Pemrograman PHP 4. Elex Media Komputindo. Jakarta

[9]. Whitten, Jeffrey L \& Bentley, Lonnie D. 2007. System Analysis and Design Methods. The McGraw-Hill Companies Inc.

[10]. Jogiyanto , HM. 2000 .

[11]. Norman L Enger. 1980. Management Standard For Developing Information System. AMACOM.

[12]. Fitzgerald, Jerry., Fitzgerald, Ardra F., Stalling, Warren D. (1981). Fundamentals of Systems Analysis ( $2^{\text {nd }}$ ed). New York: John Willey \& Sons 